\title{
COVID-19 in Children and Policy of the Indonesian Government to Begins New School Year
}

\author{
Anna Wijayanti ${ }^{1}$, Ratna Dwi Wulandari ${ }^{2}$, Agung Dwi Laksono ${ }^{3}$ \\ ${ }^{1}$ Master Program in Health Policy and Administration, Faculty of Public Health, Universitas Airlangga, Indonesia, \\ ${ }^{2}$ Researcher, Department of Health Policy and Administration, Faculty of Public Health. Universitas Airlangga, \\ Indonesia, ${ }^{3}$ Researcher, National Institute of Health Research and Development, Indonesian Ministry of Health
}

\begin{abstract}
The New Coronavirus 2019 pandemic (COVID-19) is the world's health crisis. Various aspects of the virus are still unknown. As the COVID-19 virus became more prevalent, the Government of Indonesia issued several types of policies, including in the education sector, by closing schools as an emergency measure to prevent the spread of infection. But when the start of the new school year, it makes parents who have school-age children start to worry, if it will start during this pandemic. The study aimed to find a picture of the impact of the Ministry of Education's policy discourse on the start of a new school year for schoolaged children. The study design was conducted with a descriptive analysis approach which was carried out through a literature review. The results of the study found that although children tend to have mild symptoms of COVID-19, it did not mean we should ignore those who have this disease. We still need to take steps to prevent them from becoming infected. Policies for reopening schools must be carefully considered. Among them were waiting for conditions to be safe from the impact of COVID-19 following the decisions of the COVID-19 Task Force and the Ministry of Health, as well as the local government as the person in charge of basic education.
\end{abstract}

Keywords: COVID-19, new school year, health policy.

\section{Introduction}

COVID-19 pandemic is a health crisis in the world. Various aspects of the virus are still unknown. Studies show that the transmission of the COVID-19 virus is through respiratory droplets and direct contact with secretions containing the virus. The cause of the high prevalence of this disease can be attributed to the long incubation period and its transmission in periods without symptoms, mild, or before it appears. It also found viral symptoms in people with chronic diseases, such as cardiovascular disease, diabetes, cancer, hypertension,

\footnotetext{
Corresponding Author:

Ratna Dwi Wulandari

Faculty of Public Health Universitas Airlangga, Indonesia

e-mail: ratna-d-w@fkm.unair.ac.id
}

and chronic respiratory diseases. The risk of viral infection increases with age ${ }^{1}$.

As the COVID-19 virus became more prevalent, the Government of Indonesia issued several policies, including in the field of education. The government closed schools nationally as an emergency measure to prevent the spread of infection. Massive efforts were made by schools and teachers at all levels of education to create lectures, or provide course material, and examinations, online, in a short time. Online learning activities are not a new thing for school children, because before they were accustomed to doing semester tests online. It's just that now they have to start adapting again by providing online subject matter. The virtual semester has also begun in many parts of the country that were affected first. This policy helps alleviate many parents' concerns about their children's educational attainment, by ensuring that school learning is largely uninterrupted. But when the new school year will start 
again, parents who have school-age children will start to worry, if it will start during this pandemic. Based on the background description, the study aimed to find out the impact of the Ministry of Education's policy discourse on the commencement of the new school year in schools with children of school-age children.

\section{Method}

The method used in this research was the study of literature, which was the study of the object of research in the form of literary works, whether in the form of scientific journals, books, articles in the mass media, or statistical data. The literature would be used to examine research problems and how to deal with them. The nature of the study conducted was descriptive analysis which was to give a picture to the reader so that it could be a medium of public education. The type of data used was secondary data.

\section{Findings:}

COVID-19 in children: COVID-19 is a new type of coronavirus that has infected people from many countries in the world. Early reports indicate that children are relatively protected from this virus compared with adults. The mission of the World Health Organization's collaboration with China in February 2020 on Coronavirus Disease found that only $2.4 \%$ of cases were in those under the age of $19^{2}$. Besides, the severity of the disease in infected children is less than the total infected population. Only $2.5 \%$ of children suffer from severe illness (compared to $13.8 \%$ overall) and $0.2 \%$ of children suffer from critical illness (compared to $6.1 \%$ overall).Severe illness is defined as dyspnoea, tachypnoea, hypoxia, or infiltrates that affect more than $50 \%$ of the lung space within 48 hours, and critical illness is defined as respiratory failure, septic shock or multi-organ failure. Although the number of reported cases is quite small, young infants appear to have a relatively low level of influence; one study of nine infected infants found that none needed intensive care or had significant complications. However, certain pediatric populations, such as babies born prematurely, tend to be very vulnerable, with one death confirmed in this subgroup. Further evidence is likely to emerge over time about how children globally will overcome this epidemic disease ${ }^{3}$.

The immune systems of children and adults are different, both in terms of their composition and functional responsiveness ${ }^{4}$. Besides, there are differences in the immune systems of very young children, preschoolers, and adolescents. During the early weeks of life, newborn human babies are faced with a series of exposures to new environments that undergo dramatic changes ${ }^{5}$. Another difference between newborns and older children is the presence of several maternal antibodies during the first months of life. These antibodies do not include new viruses such as SARS$\mathrm{CoV} 2^{6}$. One possible explanation for the presentation of COVID-19 milder disease in children is that children have a qualitatively different response to the SARS$\mathrm{CoV} 2$ virus than adults. Another possibility is that the presence of other simultaneous viruses in the lung mucosa and airways, which is common in children, can limit the growth of SARS-CoV2 through direct virusto-virus interaction and competition ${ }^{7}$. This is consistent with data emerging from the current pandemic, which has shown a relationship between the number of copies of the virus and the severity of COVID-198. This condition could also explain some of the tragic deaths of health care workers, who may have been exposed to a large number of SARS-Cov2 viruses.

Another possible theory for mild COVID-19 infection in children is related to differences in the expression of angiotensin-converting enzyme (ACE) 2 receptors needed for binding to SARS-Cov2 infection. These receptors are expressed in the airways, lungs, and intestines, but not in immune cells 9 . Treatment with ACE inhibitors or angiotensin receptor blockers induces ACE2 expression. Both of these therapies are common in adults with hypertension and less frequently in children. This has led some to believe that increased ACE2 expression may explain worse results in adults infected with SARS-Cov2, but others have reported the protective effect of ACE2 during lung infections ${ }^{10}$. Although children tend to have mild forms of COVID-19 symptoms, that does not mean that we should ignore those who have this disease.

Government Policies in the Field of Education: The government has issued a policy for education which is to close schools and provide subject matter and examinations online. Although these steps and efforts are highly commendable and necessary, there is reason to be worried because the closure of long schools and confinement at home during an outbreak may harm the physical and mental health of children ${ }^{11,12}$. This can be proven when inviting or when children leave school activities (for example weekends and school holidays), they are physically less active, have more time to play 
with gadgets, irregular sleep patterns, and fewer dietary patterns. Resulting in weight gain, and loss of physical fitness $^{13}$. Such negative effects on health are likely to be far worse when children are locked up in their homes without outdoor activities and interactions with friends of the same age during the outbreak.

Perhaps this pandemic issue is more important, but don't overlook the psychological impact on children and adolescents. Stress resulting from prolonged quarantine duration, fear of infection, frustration and boredom, inadequate information, lack of direct contact with classmates, friends, and teachers, lack of personal space at home, and family financial losses, can have more problematic effects and lasts long in children and adolescents $^{12}$. According to Sprang and Silman show that the average post-traumatic stress score is four times higher in children who have been quarantined than those who are not quarantined ${ }^{14}$. Furthermore, the interaction between lifestyle changes and psychosocial stresses caused by confinement at home can further exacerbate the effects on a child's physical and mental health, which can lead to recurring circles.

To reduce the consequences of confinement at home, governments, non-governmental organizations, communities, schools, and parents need to be aware of the downside of this situation and do more to deal with these problems immediately. The experience learned from previous outbreaks can be useful for designing new programs to overcome this problem in Indonesia ${ }^{15}$.

The government needs to increase awareness of the potential physical and mental health effects of confinement at home during this unusual period. The government must also provide guidelines and principles for effective online learning and ensure that the contents of school subject matter meet the educational requirements. But it is also important not to burden students. The government might mobilize available resources, involve non-governmental organizations, and create a platform to gather the best online education courses on healthy lifestyles and psychosocial support programs available for schools. For example, in addition to innovative courses for a better learning experience, promotional videos can be useful to motivate children to have a healthy lifestyle at home by increasing physical activity, having a balanced diet, regular sleep patterns, and good personal hygiene. These actions make this educational material truly effective, appropriate for their age, and interesting ${ }^{16}$.
The community can also function as a valuable resource in managing family difficulties. For example, a committee of parents can work together to bridge student needs with school requirements and advocate for children's rights to a healthy lifestyle. Psychologists can provide online services to deal with mental health problems caused by domestic conflict, tension with parents, and anxiety due to this pandemic ${ }^{15}$. Social workers can play an active role in helping parents deal with family problems arising from the situation if needed. Social safety nets or some kind of cooperative of parents can be very useful for disadvantaged families or single parents ${ }^{17}$. These services make it easily accessible to them when needed.

Schools have an important role, not only in presenting educational material to children but in offering opportunities for students to interact with teachers and get psychological counseling. Schools can actively promote health-conscious schedules, good personal hygiene, encourage physical activity, proper diets, and good sleep habits, and integrate health promotion materials into the school curriculum ${ }^{11}$.

In terms of quarantine or at home, parents are often the closest and best source for children to seek help. Closed or open communication with children is the key to identifying any physical and psychological problems and to entertain children in prolonged isolation ${ }^{18,19}$. Parents often become important role models in healthy behavior for children. Good parenting skills are very important when children are locked up at home. In addition to monitoring children's performance and behavior, parents also need to respect their identity and needs, and parents need to help children develop selfdiscipline skills. Children who are constantly exposed to news related to the epidemic, so having direct parent conversations with children about this problem can reduce their anxiety and avoid panic ${ }^{19}$. Quarantine or home activities alone can offer a good opportunity to increase interaction between parents and children, involve children in family activities, and improve their independent skills ${ }^{18}$. With the right care approach, family ties can be strengthened, and the psychological needs of children are met $^{20}$.

Indonesian Government's Policy to Begin a New Academic Year: The Ministry of Education will reopen schools simultaneously, starting a new school year, but not with face-to-face teaching and learning method. The method of learning for the new school year will 
depend on the conditions of each region. Terms related to this condition will later be announced by the Ministry of Education, and explain that the start date of the new school year can vary by region because the education calendar is made by the local government. Generally, the new school year begins in the third week of July. But this is only for areas in the green zone and eligible ${ }^{21}$.

In anticipation of the fact that the pandemic has not ended until the end of the year, the Ministry of Education prepares a home learning scenario until the end of 2020 . To date $97.6 \%$ of schools conduct distance learning, 54\% have done full distance learning, namely teachers and students teaching and learn from home. The remaining $2.4 \%$ have not done it because the area is not affected by the pandemic or do not have supporting devices. Besides, the Ministry of Education has made several programs such as Learning Houses, Learning from Home, on television, and radio to support the learning process.

Other news added that the reopening of schools is also awaiting safe conditions from the effects of COVID-19, following the decisions of the COVID-19 Task Force and the Ministry of Health. Therefore, optimistic estimates of schools opening in mid-July according to the education calendar, concerning the health protocol. If by mid-July the COVID-19 case was still high and large-scale social restrictions were still in place, distance learning for early childhood education, basic education, and secondary education would continue ${ }^{22,23}$.

\section{Conclusions}

Even though children tend to have mild forms of COVID-19 symptoms, that does not mean that we should ignore those who have this disease. We still need to take steps to prevent them from becoming infected if we want to reduce the pandemic. Children may be able to transmit the virus, and they have been found to store large amounts of the virus, even without showing symptoms but they are not aware of it.

The policy to reopen schools must take into account the various related parties, including waiting for safe conditions from the impact of COVID-19 following the decision of the COVID-19 Task Force and the Ministry of Health and local government as the person in charge of basic education. The risk is too great for the education sector because what is faced is children. In addition to having a bad impact on students, the government will also get a bad spot, if it is mismanaged and results in new clusters.

Acknowledgments: The author would like to thank Universitas Airlangga, which has allowed completing this final project.

Source of Funding: Self-funding

\section{Conflict of Interests: Nil}

Ethical Clearance: The study was conducted using secondary data that has been published so that ethical clearance is not needed for implementation.

\section{References}

1. Taheri S. A Review on Coronavirus Disease (COVID-19) and What is Known about it. Depiction Health. 2020 Jan;11(1):87-93.

2. World Health Organization. World Health Organization-China Joint Mission on Coronavirus Disease. In Geneva: Google Scholar; 2020.

3. Zhu H, Wang L, Fang C. Clinical analysis of 10 neonates born to mothers with 2019-nCoV pneumonia. Transl Pediatr. 2020 Feb;9(1):51-60.

4. Simon AK, Hollander G, McMichael A. Evolution of the immune system in humans from infancy to old age. Proceedings of The Royal Society Biological Sciencesal [Internet]. 2015 Dec 22; Available from: https://royalsocietypublishing.org/ doi/full/10.1098/rspb.2014.3085

5. Olin A, Henckel E, Yang Chen, Tadepally Lakshmikanth, Christian Pou, Jaromir Mikes, et al. Stereotypic Immune System Development in Newborn Children. Pubmed. 2018 Aug 23;174(5):1277-92.

6. Pau C, Nkulikiyimfura D, Henckel E, Olin A, Tadepally Lakshmikanth, Mikes J, et al. The Repertoire of Maternal Anti-Viral Antibodies in Human Newborns. Nat med. 2019 Apr;25(4):591596.

7. Nickbakhsh S, Mair C, Matthews L. Virus-virus interactions impact the population dynamics of influenza and the common cold. Proceedings Natlonal Academy Sci USA. 2019 Dec 26;116(52):27142-50.

8. Liu Y, Yan L-M, Wan L. Viral dynamics in mild and severe cases of COVID-19. Lancet Infect Dis 2020. 2020 Mar 19;20(6):656-7.

9. Uhlen M, Karlsson M, Zhong W. A genome-wide 
transcriptomic analysis of protein-coding genes in human blood cells. Science [Internet]. 2019 Dec 20;366. Available from: https://pubmed.ncbi.nlm. nih.gov/31857451/?dopt=Abstract

10. Imai Y, Kuba K, Rao S. Angiotensin-converting enzyme 2 protects from severe acute lung failure. Nature . 2005 Jul 7;436(7047):112-6.

11. Brazendale K, Beets M, Weaver R. Understanding differences between summer vs. school obesogenic behaviors of children: the structured days hypothesis. Int J Behav Nutr Phys Act. 2017 Jul 26;14(1): 100 .

12. Brooks S, Webster R, Smith. The psychological impact of quarantine and how to reduce it: rapid review of the evidence. 2020 Mar 14;395:912-20.

13. Wang G, Zhang J, Lam S. Ten-year secular trends in sleep/wake patterns in Shanghai and Hong Kong school-aged children: a tale of two cities. Journal Clin Sleep Med. 2019 Oct 15;15(10):1495-502.

14. Sprang G, Silman. Posttraumatic stress disorder in parents and youth after health-related disasters. Disaster Med Public Health Prep. 2013 Feb;7(1):105-10.

15. Decosimo C, Hanson J, Quinn M, Badu P, Smith E. Playing to live: outcome evaluation of a community-based psychosocial expressive arts program for children during the Liberian Ebola epidemic. Glob Ment Health (Camb) [Internet]. 2019 Apr 22;6(3). Available from: https://pubmed. ncbi.nlm.nih.gov/31143464/?dopt=Abstract

16. Mason F, Farley A, Pallan M. Effectiveness of a brief behavioural intervention to prevent weight gain over the Christmas holiday period: randomised controlled trial. BMJ [Internet]. 2018 Dec 10;363. Available from: https://www.bmj.com/content/363/ bmj.k4867.full
17. Liu S, Yang L, Zhang C. Online mental health services in China during the COVID-19 outbreak. Lancet Psychiatry. 2020 Apr 1;7(4):E17-8.

18. NHC. National Health Commission of the People's Republic of China Guideline for psychological crisis intervention during 2019-nCoV. 2020; Available from: http://www.nhc.gov.cn/jkj/s3577 /202001/6adc08b966594253b2b791be5c3b9467. shtml

19. WHO. WHO Coronavirus disease (COVID-19) advice for the public [Internet]. 2020. Available from: https://www.who.int/emergencies/diseases/ novel-coronavirus-2019/advice-for-public

20. Perrin E, Leslie L, Boat T. Parenting as primary prevention. JAMA Pediatr. 2016;170(7):637-8.

21. CNN. Kemendikbud Buat Skenario Belajar di Rumah sampai Akhir 2020. 2020; Available from: https://www.cnnindonesia. com/nasional/20200424114337-20-496861/ kemendikbud-buat-skenario-belajar-di-rumahsampai-akhir-2020?

22. Kompas. Mendikbud Siapkan Skenario Memulai Tahun Ajaran Baru di Tengah Pandemi Penulis : Tsarina Maharani Editor : Krisiandi. Kompas.com [Internet]. 2020 May 20; Available from: https:// nasional.kompas.com/read/2020/05/20/19472611/ mendikbud-siapkan-skenario-memulai-tahunajaran-baru-di-tengah-pandemi.

23. Kam K, Yung C, Cui L. A well infant with coronavirus disease 2019 (COVID-19) with high viral load. Clinical Infectious Diseases [Internet]. 2020 Feb 28; Available from: https://academic. oup.com/cid/advance-article/doi/10.1093/cid/ ciaa201/5766416 